
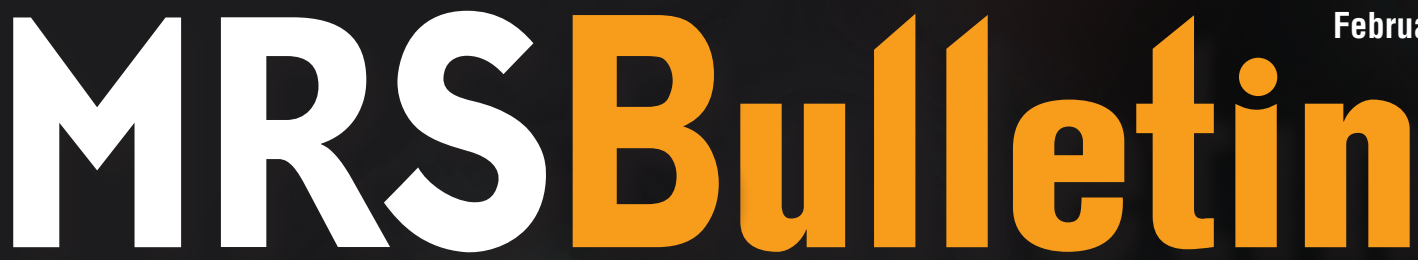

February 2012 Vol. 37 No. 2 www.mrs.org/bulletin

MRSS MATERIALS RESEARCH SOCIETY

Advancing materials. Improving the quality of life.

\title{
Resistive switching phenomena in thin films: Majerials, devices, and applications
}

\section{ALSO IN THIS ISSUE}

The second revolution in atom probe tomography 


\section{PARTICLE ACCELERATOR SYSTEMS}

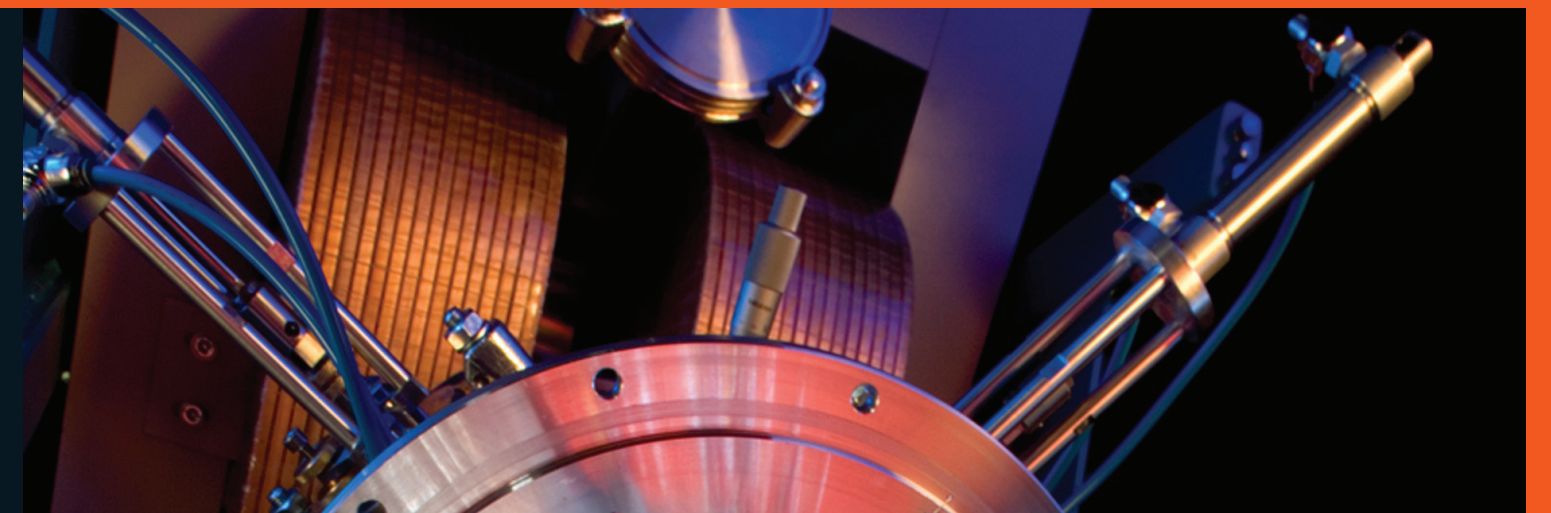

口 Ion Accelerator Systems

- Ion Implanters

- Systems for lon Beam Analysis

- Accelerator Mass Spectrometers

- Systems for $\boldsymbol{\mu}$-beam Applications

- Neutron Generator Systems

Electron Accelerator Systems

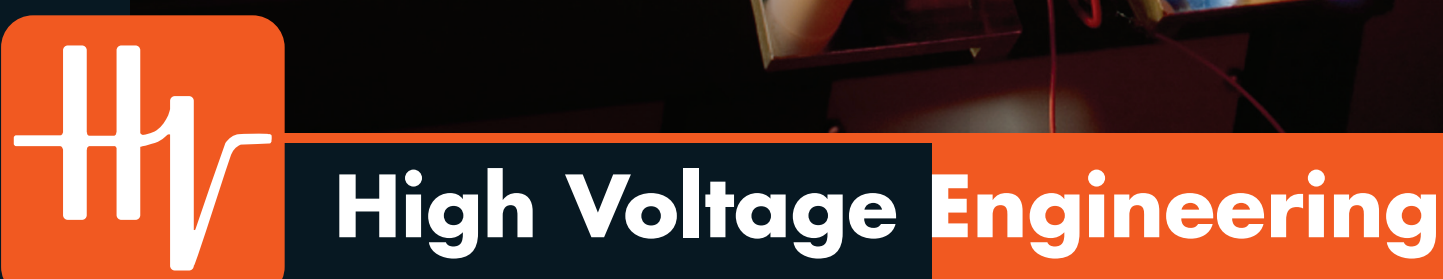

High Voltage Engineering Europa B.V.

P.O. Box 99, 3800 AB Amersfoort, The Netherlands Tel: $31334619741 \cdot$ info@highvolteng.com 


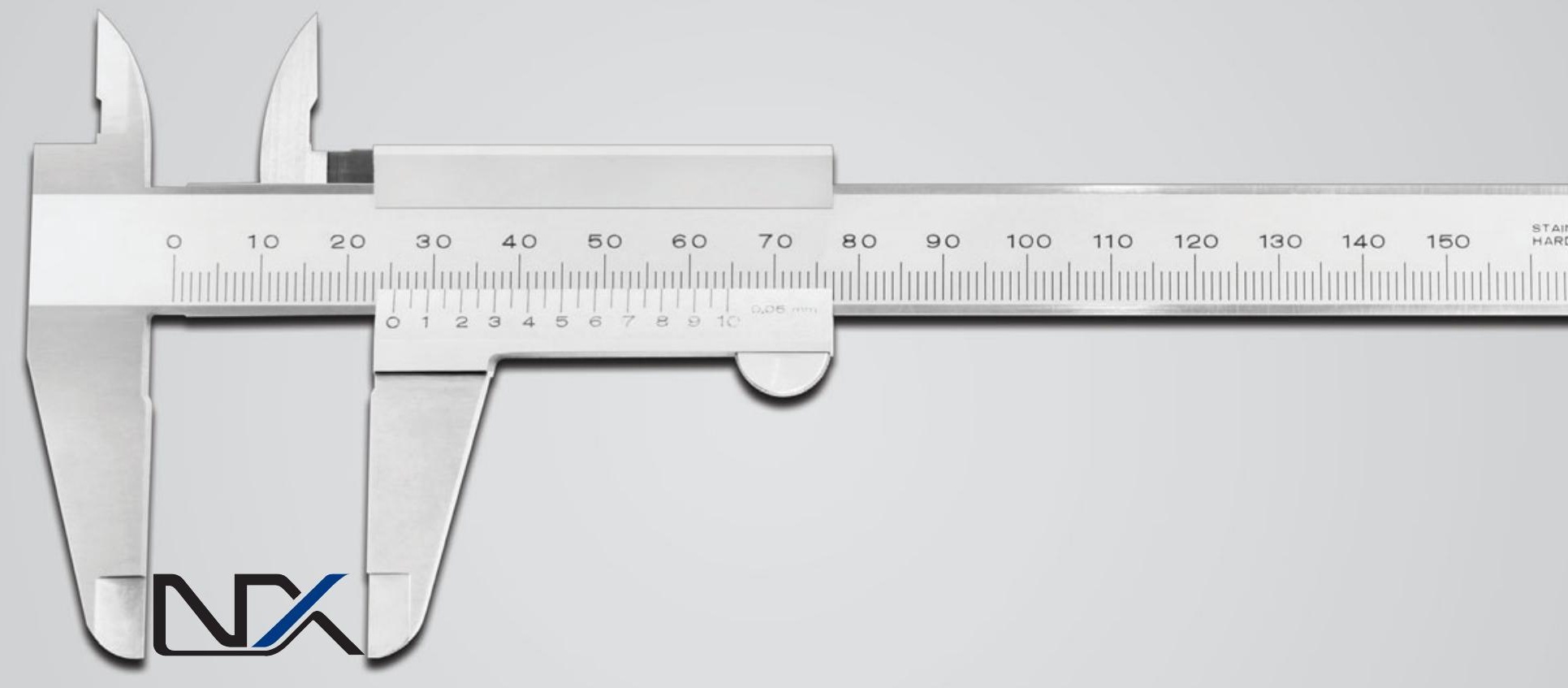

\section{The World's Most}

\section{Accurate AFM}

Data accuracy is of paramount importance to nanotechnology researchers as the credibility of their research depends upon accurate results. The NX10, the world's most accurate AFM, is the flagship AFM of Park Systems' new product line. The NX10 brings unparalleled imaging accuracy, scan speeds, and tip life to the next generation of researchers, all at an affordable price. The NX platform builds on Park Systems' 28 years of technology leadership in AFM data accuracy, and its reputation as the leading nanotechnology solutions partner to research and industry.

Come and visit us at www.parkAFM.com/nx and learn about what makes the NX10 a long-awaited and game-changing product from Park Systems. The NX10 is the world's premium research-grade True Non-Contact AFM, featuring industry-leading Z-servo speed, XYZ scanner linearity, closed-loop detector noise, and minimized thermal drift. As Park Systems' most user-friendly AFM, the NX10 makes AFM convenient and intuitive for new and experienced users alike.

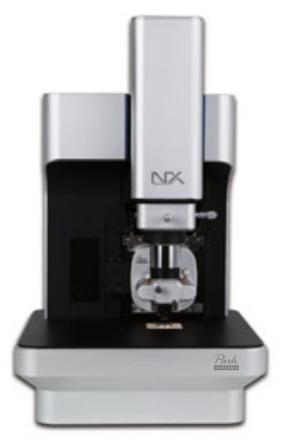




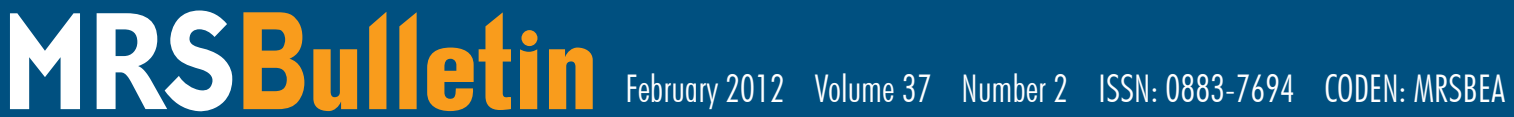
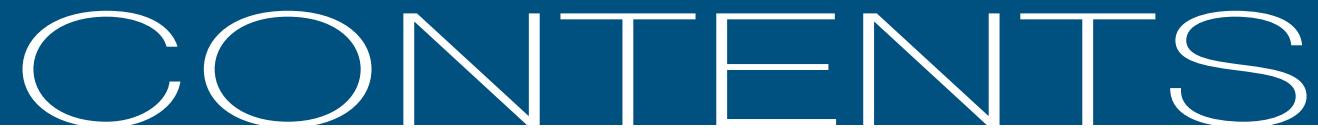

\section{RESISTIVE SWITCHING PHENOMENA IN THIN FILMS: MATERIALS, DEVICES, AND APPLICATIONS}

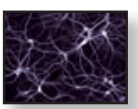

108 Resistive switching phenomena in thin films: Materials, devices, and applications D.B. Strukov and H. Kohlstedt, Guest Editors

\section{Meet Our Authors}

\section{Phase change materials}

Simone Raoux, Daniele Ielmini, Matthias Wuttig and llya Karpov

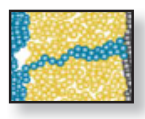

124 Electrochemical metallization cells-blending nanoionics into nanoelectronics?

Wei Lu, Doo Seok Jeong, Michael Kozicki, and Rainer Waser

131 Metal oxide memories based on thermochemical and valence change mechanisms

J. Joshua Yang, Isao H. Inoue, Thomas Mikolajick, and Cheol Seong Hwang

138 Ferroelectric and multiferroic tunnel junctions E.Y. Tsymbal, A. Gruverman, V. Garcia, M. Bibes, and $A$. Barthélémy

144 Organic resistive nonvolatile memory materials Takhee Lee and Yong Chen

\section{TECHNICAL FEATURE}

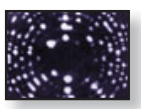

150 The second revolution in atom probe tomography

2011 MRS Innovations in Materials

\section{Characterization Award}

Thomas F. Kelly and David J. Larson

\section{DEPARTMENTS}

\section{NEWS \& ANALYSIS}

\section{Research/Researchers}

- Silicon nanowire FET-integrated nanopore sensor uses local electrical potential detection as a novel method for DNA sequencing Rufina S.A. Sesuraj

- Functional ferroelectric tunnel-junction memories demonstrated Steven Spurgeon

- Electronic properties of graphene modulated with chemical functionalization Steven Trohalaki

- Self-assembled curved 3D structures with integrated microfluidic network achieved by differential crosslinking of polymer thin films Mousumi Mani Biswas

- Hollow spacers lead to new possibilities in superlattice design Kevin P. Herlihy

- Hydrogen at room temperature is squeezed to become a metal Rich Louie

- High-resolution mapping of soft surface chemistry achieved Tobias Lockwood

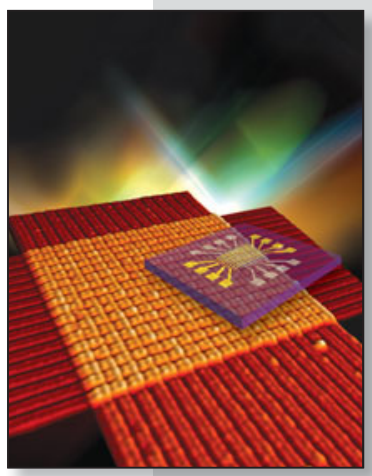

ON THE COVER

Resistive switching phenomena in thin films: Materials, devices, and applications. This issue of MRS Bulletin starts by reviewing some of the promising applications of resistive switching phenomena in thin-film devices, and then follows with the detailed discussion of current state-of-the-art understanding of the physics behind this phenomenon in several major classes of material systems. The cover shows a $17 \times 17$ crossbar array of 50 -nm-thick $\mathrm{TiO}_{2}$ memristors defined by 50 -nm-wide platinum electrodes spaced by $50 \mathrm{~nm}$ gaps. (Image courtesy of J. Joshua Yang, G. Medeiros-Ribeiro, and R. Stan Williams of Hewlett Packard Labs.) A schematic illustrating a crossbar array memory circuit with a unit cell size of $100 \times 100 \mathrm{~nm}^{2}$, fabricated by a direct metal-transfer process, is superimposed on the right (adapted from Kim et al., Adv. Mater., 23, 2104 [2011]). See the technical theme that begins on page 108. 


\section{MRS}

MATERIALS RESEARCH SOCIETY

Advancing materials. Improving the quality of life.

www.mrs.org/bulletin

\section{Science Policy}

- New NSF program connects researchers, entrepreneurs Kendra Redmond

- NSF announces new workplace flexibility policies

- Directions in the Philippines for emerging science research set

\section{SOCIETY NEWS}

- Preview: 2012 Materials Research Society Spring Meeting \& Exhibit

- 2011 World Materials Summit addresses energy, sustainability, and water

- MRS invites nominations for the Von Hippel Award, Turnbull Lectureship, MRS Medal, and Materials Theory Award

- Conference on microwave energy application to be held July

\section{CAREER CENTRAL}

\section{FEATURES}

\section{Books}

- Hume-Rothery rules for structurally complex alloy phases, Uichiro Mizutani Reviewed by N. Balasubramanian

- Introductory nanoscience: Physical and chemical concepts, Masaru Kuno

Reviewed by Yumi ljiri

\section{Image Gallery}

Look Again

\section{ADVERTISERS IN THIS ISSUE}

Page No.

American Elements ...0utside back cover High Voltage Engineering ............... Inside front cover MMR Technologies, Inc. ..................................... 123

Park Systems, Inc................................................. 97

Solartron Analytical (AMETEK) ..... Inside back cover SVC Publications.

\section{www.mrs.org/bulletin}

MRS members-access MRS Bulletin online

www.materialsforenergy.org

Join the conversation in the Materials for Energy blog

\section{www.mrs.org/mymrs}

MRS Publications Alert-

receive advance Table of Contents by email

http://journals.cambridge.org/

mrsbulletin-rss

Subscribe TODAY to the MRS Bulletin RSS Feed 


\section{About the Materials Research Society}

The Materials Research Society (MRS), a not-for-profit scientific association founded in 1973, promotes interdisciplinary goal-oriented basic research on materials of technological importance. Membership in the Society includes almost 16,000 scientists, engineers, and research managers from industrial, government, and university research laboratories in the United States and over 80 countries.

The Society's interdisciplinary approach differs from that of single-discipline professional societies because it promotes information exchange across the many technical fields touching materials development. MRS sponsors three major international annual meetings encompassing approximately 125 topical symposia, and also sponsors numerous single-topic scientific meetings. The Society recognizes professional and technical excellence and fosters technical interaction in local geographic regions through Sections and University Chapters.

MRS participates in the international arena of materials research through the International Union of Materials Research Societies (IUMRS). MRS is a member of the Alliance for Science \& Technology Research in America and is an affiliate of the American Institute of Physics.

MRS publishes The MRS Online Proceedings Library, MRS Bulletin, Journal of Materials Research, MRS Communications, and other publications related to current research activities.

\section{MRS BOARD OF DIRECTORS}

President Bruce M. Clemens, Stanford University, USA

Immediate Past President James J. De Yoreo, Lawrence Berkeley Nationa Laboratory, USA

Vice President and President-Elect Orlando Auciello, Argonne Nationa Laboratory, USA

Secretary Sean J. Hearne, Sandia National Laboratories, USA

Treasurer Michael R. Fitzsimmons, Los Alamos National Laboratory, USA

Executive Director Todd M. Osman, Materials Research Society, USA

Wade Adams, Rice University, USA

Ana Claudia Arias, University of California-Berkeley, USA

Shenda Baker, Synedgen, Inc./Harvey Mudd College, USA

Tia Benson Tolle, U.S. Air Force Research Laboratory, USA

Duane B. Dimos, Sandia National Laboratories, USA

Chang-Beom Eom, University of Wisconsin-Madison, USA

Eric Garfunkel, Rutgers University, USA

J. Murray Gibson, Argonne National Laboratory, USA

Oliver Kraft, Karlsruhe Institute of Technology, Germany

Hideki Matsumura, Japan Advanced Institute of Science and Technology, Japan

Ainissa Gweneth Ramirez, Yale University, USA

Stephen K. Streiffer, Argonne National Laboratory, USA

Susan E. Trolier-McKinstry, The Pennsylvania State University, USA

Pierre Wiltzius, University of California-Santa Barbara, USA

\section{MRS OPERATING COMMITTEE CHAIRS}

Academic Affairs M. Stanley Whittingham, SUNY-Binghamton, USA Awards Julia R. Weertman, Northwestern University, USA

Government Affairs Nabil Bassim, U.S. Naval Research Laboratory, USA

Meetings Committee David S. Ginley, National Renewable Energy

$$
\text { Laboratory, USA }
$$

Membership Yves Chabal, The University of Texas at Dallas, USA

Public Outreach Aditi Risbud, Lawrence Berkeley National Laboratory, USA

Publications Paul McIntyre, Stanford University, USA

MRS OFFICE OF PUBLIC AFFAIRS

Ron Kelley 499 South Capitol St. SW, Suite 600, Washington, DC 20003
Editor

Gopal R. Rao, rao@mrs.org

Managing Editor

Judy Meiksin, meiksin@mrs.org

Technical Editor

Lori A. Wilson, Iwilson@mrs.org

Editorial Assistants

Ben Moriarty, moriarty@mrs.org

Mary Wilmoth

Associate Technical Editor

Aniketa Shinde

Art Director

Kasia M. Bruniany

Production/Design

Andrea Pekelnicky, Christopher R. Roberts, and TNQ

Production Editor

Catherine Paduani

Science News Editor

Tim Palucka

Principal Development Editor

Elizabeth L. Fleischer

Director of Publications and Marketing

Eileen Kiley Novak
Guest Editors

D.B. Strukov and H. Kohlsted

Energy Quarterly

Steve M. Yalisove (Chair),

V.S. Arunachalam, Anshu Bharadwaj,

David Cahen, Russell R. Chianelli,

George Crabtree, Abdelilah Slaoui,

Guillermo Solórzano,

and M. Stanley Whittingham

Advertising/Sponsorship

Mary E. Kaufold, kaufold@mrs.org

Donna L. Watterson, watterson@mrs.org

Member Subscription

Michelle Judt, judt@mrs.org

Non-Member Subscriptions

subscriptions_newyork@cambridge.org

\section{EDITORIAL BOARD}

Paul S. Drzaic (Chair), Apple, Inc., USA

V.S. Arunachalam, Center for Study of Science, Technology \& Policy, India

Marie-Isabelle Baraton, University of Limoges, France

Robert C. Cammarata, Johns Hopkins University, USA

Laura Fornaro, University of Uruguay, Uruguay

Hanns-Ulrich Habermeier, Max Planck Institute for Solid State Research, Germany

Fiona C. Meldrum, University of Leeds, UK

Amit Misra, Los Alamos National Laboratory, USA

Julie A. Nucci, Cornell University, USA

Linda J. Olafsen, Baylor University, USA

David N. Seidman, Northwestern University, USA

Carol Trager-Cowan, University of Strathclyde, UK

Julia R. Weertman, Northwestern University, USA

Eric Werwa, Washington, DC, USA

Steve M. Yalisove, University of Michigan, USA

\section{VOLUME ORGANIZERS}

2013 Mark T. Lusk, Colorado School of Mines, USA Eva Olsson, Chalmers University of Technology, Sweden Birgit Schwenzer, Pacific Northwest National Laboratory, USA James W. Stasiak, Hewlett-Packard Co., USA

2012 Lei Jiang, Chinese Academy of Sciences, China Sergei V. Kalinin, Oak Ridge National Laboratory, USA Stéphanie P. Lacour, EPFL, Switzerland Steven C. Moss, Aerospace Corporation, USA

2011 Kyoung-Shin Choi, Purdue University, USA Reuben T. Collins, Colorado School of Mines, USA Sean E. Shaheen, University of Denver, USA Kathryn Uhrich, Rutgers, the State University of New Jersey, USA

MRS Bulletin (ISSN: 0883-7694, print; ISSN 1938-1425, online) is published 12 times a year by the Materials Research Society, 506 Keystone Drive, Warrendale, PA 15086-7573. Copyright $\odot$ 2012, Materials Research Society. Permission required to reproduce content. Periodical postage paid at New York, NY, and at additional mailing offices. POSTMASTER: Sen address changes to MRS Bulletin in care of the Journals Department, Cambridge University Press, 100 Brook Hill Drive, West Nyack, NY 10994-2113, USA. Printed in the U.S.A.

Membership in MRS is $\$ 115$ annually for regular members, $\$ 30$ for students. Dues include an allocation of $\$ 29$ ( $\$ 17$ for students) to a subscription to MRS Bulletin. Individual member subscriptions are for personal use only. Non-member subscription rates are $\$ 363$ for one calendar year (12 issues) within North America and $\$ 436$ elsewhere. Requests from subscribers for missing journal issues will be honored without charge only if received within six months of the issue's actual date of publication.

MRS Bulletin is included in Current Contents ${ }^{\circledast / E n g i n e e r i n g, ~ C o m p u t i n g, ~ a n d ~ T e c h n o l o g y ; ~ C u r r e n t ~ C o n t e n t s ~} \circledast /$ Physical, Chemical, and Earth Sciences, the SciSearch ${ }^{\oplus}$ online data-

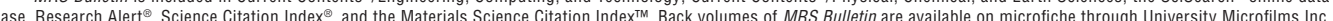
300 North Zeeb Road, Ann Arbor, MI 48106, USA. 